\title{
Representasi Anak-Anak Melalui Komik Doraemon Berdasarkan Pendekatan Image System
}

\author{
Fransiska Desiana Setyaningsih \\ Program Studi Ilmu Komunikasi-FISIP, Universitas Widya Mandira \\ JL Jend Ahmad Yani No.50-52, Merdeka, Lama City, Kupang City, East Nusa Tenggara 85225 \\ fransiskadesiana04@gmail.com
}

Masuk tanggal : 07-10-2018, revisi tanggal : 17-02-2019, diterima untuk diterbitkan tanggal : 22-03-2019

\begin{abstract}
This study examines the profiles of children represented through comics circulating in Indonesia based on image system. In the various comics, children are often used as objects or main characters in a comic or story, one of them is Doraemon Comic. In Doraemon comic, children are shown as, who like to play, imitate, a little whiny but on the other side like to help an sometimes show an independent attitude. Therefore, using descriptive methods, this study is limited to the representation of the four main characters of children in Doraemon Comic. Data collected through dokument study. The aim of this study is to describe the representation of children through the Doraemon comics. The results of the study show that children represented through Doraemon Comics are: happy to play, like to move, children are whiny and love to imitate, not stand alone but are interrelated with each other, between ideational system and mediational system. The idea possessed by the author of Doraemon comics regarding children is represented through the four main figures who in their capacity indirectly act as mediators. So by reading Doraemon comics, people can know the picture of children in life.
\end{abstract}

Keywords: comic, children representation, ideational system, mediational system

\begin{abstract}
Abstrak
Penelitian ini mengkaji profil anak-anak yang direpresentasikan melalui komik yang beredar di Indonesia berdasarkan sistem citra. Dalam berbagai komik yang beredar, anakanak sering dijadikan sebagai objek atau tokoh utama dalam cerita, salah satunya Komik Doraemon. Dalam komik Doraemon, anak-anak dengan segala tingkah polahnya seperti senang bermain, senang meniru, sedikit cengeng, suka membantu dan bisa bersikap mandiri, ditampilkan dalam berbagai situasi baik di rumah, di sekolah maupun di ruang publik lainnya seperti taman, pantai, dsb. Penelitian dibatasi pada representasi empat tokoh utama anak-anak dalam Komik Doraemon ini menggunakan metode deskriptif kualitatif dimana teknik pengumpulan data yang digunakan adalah studi dokumen. Tujuan dari penelitian ini adalah mendeskripsikan representasi anak-anak melalui komik Doraemon. Hasil penelitian sendiri menunjukkan bahwa anak-anak yang direpresentasikan melalui komik Doraemon sebagai anak-anak yang senang bermain, senang bergerak, cengeng dan senang meniru, ternyata tidak berdiri sendiri melainkan saling berkaitan satu dengan yang lain, antara sistem gagasan atau ide dan sistem mediasi. Ide yang dimiliki oleh pengarang direpresentasikan melalui keempat tokoh utamanya yang dalam kapasitasnya secara tidak langsung berperan sebagai mediasi. Sehingga dengan membaca komik Doraemon, seseorang dapat mengetahui gambaran anak-anak dalam kehidupan.
\end{abstract}

Kata Kunci: komik, representasi anak-anak, sistem ide, sistem mediasi 


\section{Pendahuluan}

Dunia anak-anak adalah dunia bermain. Mereka senantiasa melakukan berbagai kegiatan yang membangkitkan keceriaan dan kegembiraan. Anak-anak juga dikenal sebagai sosok yang pemaaf dan polos. Berdasarkan pengamatan awal yang dilakukan terhadap anak-anak usia TK-SD, jika dalam bermain bersama terjadi perselisihan atau bahkan hingga perkelahian, hal tersebut tidak berlangsung lama. Ibaratnya, hari ini berkelahi, besok sudah bermain bersama kembali. Gambaran mengenai anak-anak seperti ini mudah dijumpai terutama dalam komik yang khusus diperuntukkan bagi anak-anak. Gambaran yang diperoleh makin lama makin menguat, pada akhirnya dapat menjadi anggapan baru atau ideologi baru dalam benak masyarakat.

Ideologi sendiri diartikan sebagai pikiran yang terorganisir, yang sistematis, mengenai apapun di dunia, berkaitan dengan nilai, orientasi dan kecenderungan yang saling melengkapi sehingga membentuk perspektif-perspektif ide. Perspektifperspektif ide yang terbentuk kemudian diungkapkan atau disebarluaskan melalui teknologi media dan komunikasi antarpribadi. sehingga seseorang akan menganut ideologi tertentu yang diterima luas, sebab, ideologi memang tidak terlepas dari sesuatu yang dominan atau ideologi dominan.

Raymond Williams menyebut ideologi sebagai seperangkat ide-ide yang muncul dari seperangkat kepentingan material tertentu atau lebih luas, muncul dari sebuah kelas atau kelompok tertentu (Lull, 1995). Sehingga dapat dikatakan bahwa suatu ideologi bukan merupakan sesuatu yang lahir dengan sendirinya, melainkan ada upaya dari kelas tertentu untuk mendominasi kelas yang lain. Hal ini menunjukkan bahwa sebagian orang, terutama mereka yang kritis memandang ideologi sebagai ketertarikan material yang berkaitan dengan ekonomi.

Keefektifan penyebaran ideologi dominan tergantung pada pemanfaatan sistem citra secara strategis, yang terdiri dari dua tipe, yakni sistem gagasan dan sistem mediasi. Sistem citra melibatkan pemahaman dari representasi ideologi dan pemanfaatan teknologi komunikasi, yang pada akhirnya dapat mendorong penerimaan khalayak terhadap ideologi tertentu. Gambaran sistem gagasan dapat diilustrasikan sebagai suatu susunan unit-unit dari gambaran gagasan dengan bentuk organisasi yang komplek yang menekankan dan merujuk pada interpretasi. Ilustrasinya sebagai berikut ini :

Ideational Systems

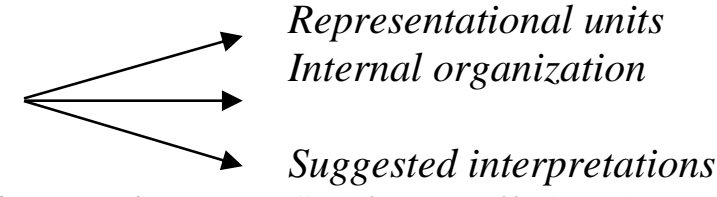

Bagan 1: Ideational System (Sumber : Lull, 1995) 
Fransiska Desiana Setyaningsih : Representasi Anak-Anak Melalui Komik Doraemon Berdasarkan Pendekatan Image System

Ketika orang merujuk pada gambaran media dalam percakapan setiap hari, ideologi sekali lagi diucapkan dan disahkan secara sosial. Lull (1995) mengilustrasikan seperti berikut ini :

Mediational Systems

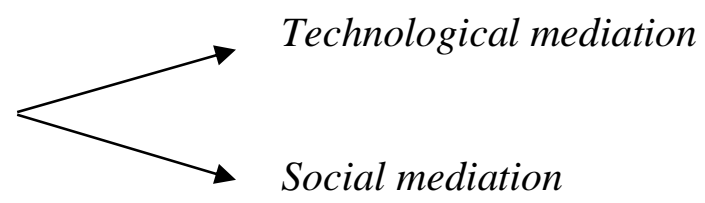

Bagan 2: Mediational System (Sumber : Lull, 1995)

Sebagai salah satu negara maju di dunia, Jepang melalui komik Doraemon, yang ditulis oleh Fujimoto Hiroshi dan Abiko Motoo yang kemudian dikenal sebagai Fujiko F. Fujio, ingin memberikan gambaran terhadap pembaca mengenai kehidupan anak-anak di Jepang. Melalui Nobita sebagai tokoh sentral atau tokoh utama, komik Doraemon meraup kesuksesan, demikian juga dengan film dan serial Doraemon. Cerita yang sederhana dengan para pemeran yang masih anak-anak (digambarkan Nobita dan kawan-kawan masih berusia sekolah dasar) membuat komik ini menarik untuk dibaca bukan saja oleh anak-anak tetapi kalangan dewasa juga menggemarinya.

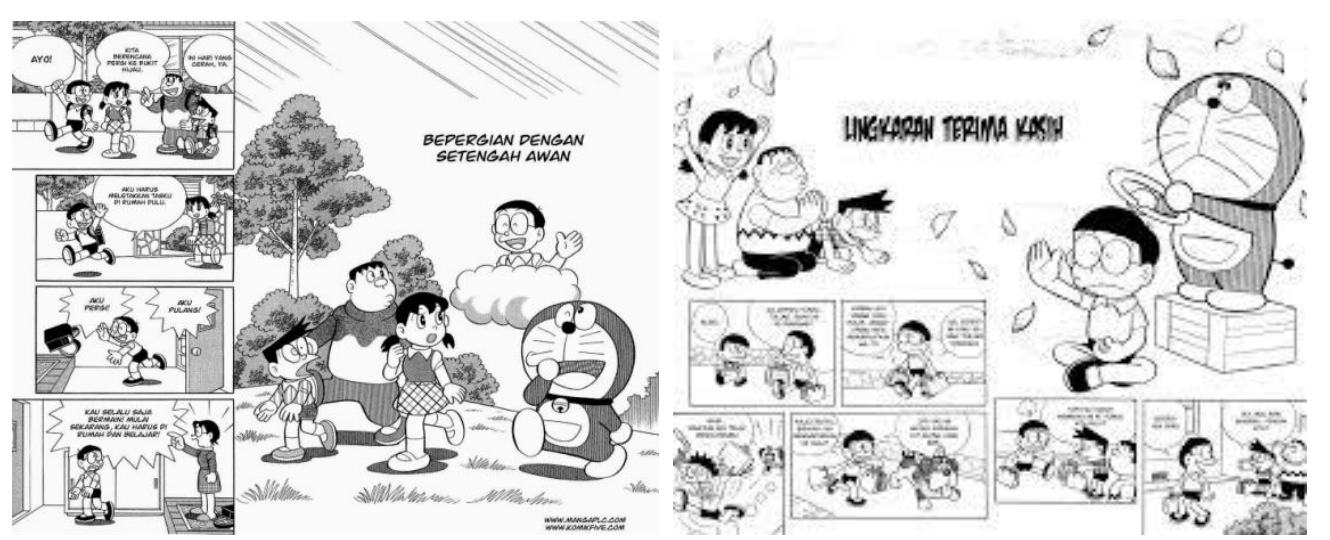

Gambar 1: Contoh Cerita dalam Komik Doraemon (Sumber: www.google.com)

Komik dapat menyampaikan gagasan, ide, pikiran dan perasaan pengarangnya sekaligus memberikan tambahan informasi dan wacana bagi pembacanya. Komik juga merupakan bagian dari budaya pop yang memiliki banyak penggemar (Wardhani, 2013). Komik sebagai salah satu bahan kajian untuk penelitian banyak dilakukan oleh akademisi maupun praktisi di bidang komunikasi.

Tulisan yang dibuat oleh Alvanov Zpalanzani dan Yasraf Amir Piliang (2010), dengan judul Framing, Pencitraan dan Panduan Grafis dalam Image Sekuensial pada Komik Perempuan dan Komik Perempuan Indonesia Kontemporer, dalam Jurnal Komunikasi Visual, menyimpulkan bahwa penggambaran perempuan dalam komik Indonesia kontemporer sangat eksploratif dalam memunculkan sistematika sekuens visual. Tulisan tersebut tidak hanya terkait pada visualisasi cerita, tetapi juga visualisasi emotif dan imajinatif yang berdasarkan kompleksitas berpikir kaum hawa. 
Penelitian lain yang masih berkaitan dengan komik adalah penelitian yang dimuat dalam Jurnal Komunikasi, dengan judul Efektivitas Komik Saku sebagai Media Pemilih dan Pemilu bagi Perempuan Marginal yang dilakukan oleh Dhyah Ayu Retno Widyastuti \& Mustika Kuri Prasela. Kesimpulan dari penelitian tersebut adalah efektivitas komik saku baru dapat ditangkap secara baik oleh perempuan yang sudah menikah dan sebelumnya telah mendapat informasi dari media massa dan perempuan yang memang sebelumnya membaca telah memiliki kesadaran gender (2010).

Berdasarkan beberapa penelitian terdahulu sebagaimana yang dipaparkan tersebut maka peneliti merasa bahwa penelitian mengenai komik dalam hal ini komik anak-anak masih perlu dilakukan terutama untuk melihat tentang penggambaran anak-anak yang ditampilkan dalam komik. Sosok anak-anak biasanya digambarkan sebagai pribadi yang lucu, menyenangkan, suka bertanya, nakal, usil, senang bermain dan sebagainya. Penggambaran anak-anak secara umum tersebut kemungkinan juga ada dalam komik Doraemon. Sehingga dalam penelitian ini, peneliti hanya melihat representasi hanya terbatas pada empat tokoh anak-anak yang terdapat dalam komik Doraemon, mereka adalah Nobita Nobi, Shizuka Minamoto, Takeshi "Gian" Goda dan Suneo Honekawa. Alasan lainnya adalah karena keempatnya dianggap dapat mewakili keberadaan anak-anak pada umumnya. Berdasarkan batasan penelitian terbut maka penelitian ini dilakukan untuk menjawab permasalahan utama yakni "bagaimana representasi anak-anak dalam komik Doraemon karya Fujiko F. Fujio?" Tujuan penelitian ini adalah mendeskripsikan representasi anak-anak melalui komik Doraemon.

\section{Metode Penelitian}

Penelitian ini menggunakan metode deskriptif yakni penelitian yang berusaha untuk menjawab masalah penelitian dengan cara menggambarkan atau mendeskripsikan suatu gejala, peristiwa yang hasilnya bisa digeneralisasikan (Kriyantono, 2008). Melalui penggunaan metode deskriptif, diharapkan peneliti memperoleh informasi berkaitan dengan representasi anak-anak dalam Komik Doraemon. Pengumpulan data akan dilakukan melalui studi dokumen, yakni dengan memilih beberapa komik-komik Doraemon dan komik-komik sejenis yang menjadikan anak-anak sebagai tokoh utama cerita komik sebagai data penunjang dalam penelitian ini. Selanjutnya dengan menggunakan teknik semiotika data akan dianalisis untuk memahami representasi anak-anak yang muncul dalam Komik Doraemon, terutama dalam bentuk nonverbal. Analisis semiotika yang digunakan ini selain bertujuan untuk mendeskripsikan makna pesan yang kelihatan, juga dapat digunakan untuk mendeskripsikan makna pesan yang tidak kelihatan atau tersembunyi.

\section{Hasil Penemuan dan Diskusi}

Pemaparan hasil penelitian ini akan dilakukan sekaligus, dimana data penelitian disajikan sekaligus dengan analisis dan interpretasinya. Oleh karena itu pada bagian ini akan dibahas dua hal sesuai dengan masalah penelitian. 
Tokoh utama dalam komik Doraemon adalah Doraemon sendiri. Selain itu ada beberapa tokoh anak-anak yang selalu mendampingi Doraemon, yakni Nobita Nobi, Shizuka Minamoto, Takeshi Goda dan Suneo Honekawa. Keempatnya adalah teman sekolah sekaligus teman bermain, mereka digambarkan tinggal dalam kompleks perumahan yang sama. Selain keempat tokoh anak-anak tersebut, beberapa cerita dalam Komik Doraemon juga kerap menampilkan tokoh anak-anak yang lain, yakni Hidetoshi Dekisugi dan Jaiko yang merupakan adik perempuan dari Takeshi Goda.

\section{Sistem Gagasan}

Image atau gambaran anak-anak seperti yang dimiliki tokoh-tokoh dalam komik Doraemon mungkin juga sering dijumpai dalam kehidupan sehari-hari. Oleh karena itu, berkaitan dengan hal tersebut maka berikut ini penjelasan tentang pembentukan image anak-anak dalam komik Doraemon yang dilihat dari dua sistem, yakni sistem gagasan dan sistem mediasi.

Seperti yang telah diungkapkan sebelumnya, ada tiga tahapan dalam pembentukan sistem idea atau gagasan. Berkaitan dengan pembentukan image anak-anak dalam komik Doraemon, maka penjelasan ketiga tahapan adalah sebagai berikut: unit representasi, internal organisasi, dan penafsiran yang disarankan.

Pertama, dikatakan sebagai unit representasi karena image anak-anak yang ditampilkan dalam media, dalam hal ini melalui komik Doraemon, tidak berdiri sendiri atau terpisah melainkan saling berkaitan antara satu dengan yang lainnya. Komik Doraemon ini ditujukan untuk anak-anak, biasanya terdiri dari beberapa cerita lepas yang ceritanya tidak saling berhubungan satu dengan lainnya, kecuali dalam seri Doraemon Petualangan yang hanya memiliki satu cerita. Hal ini dapat dilihat dari beberapa indikator berikut ini :

- Isi cerita

Kisah dalam komik Doraemon umumnya menceritakan tentang keseharian Nobi Nobita dan teman-temannya, lengkap dengan masalah yang dihadapi. Berkat bantuan peralatan canggih yang dikeluarkan Doraemon dari kantong ajaibnya, segala masalah dapat diatasi, namun tidak jarang, karena rasa ingin tahu yang besar, peralatan canggih tersebut kadang disalahgunakan dan akhirnya menimbulkan kekacauan.

- Alur cerita

Biasa dikenal juga dengan istilah plot, yang terbagi atas tiga bagian, yakni awal, tengah dan akhir. Bagian awal merupakan bagian yang menjadi pengantar untuk memasuki keseluruhan cerita. Bagian tengah merupakan bagian dimana cerita bergulir hingga mencapai klimaksnya. Bagian akhir merupakan bagian penyelesaian dari konflik yang ada dalam keseluruhan cerita.

- Latar cerita

Umumnya latar cerita yang digunakan dalam komik Doraemon mengambil tempat di sekitar tempat tinggal masing-masing tokoh, sekolah, lapangan dan bukit belakang sekolah. Namun kadang-kadang karena bisa menembus waktu, latar cerita juga bisa ke masa lalu maupun ke masa depan. 
- Perilaku tokoh cerita

Nobi Nobita dan teman-temannya adalah siswa sekolah dasar yang sama-sama duduk di kelas 4 SD. Tingkah laku yang mereka tunjukkan juga khas anak-anak, dimana suatu saat mereka bisa sangat manja, mau menang sendiri, suka pamer, namun disisi lain mereka bisa bersikap dewasa, mandiri, mau mengalah dan menolong. Untuk kemandirian, bisa dilihat dalam keseluruhan cerita dalam komik Doraemon digambarkan bahwa Nobita dan kawan-kawannya selalu berangkat dan pulang sekolah sendiri, tidak diantar dan dijemput oleh orang tua.

- Keinginan

Doraemon merupakan robot masa depan yang sanggup memenuhi berbagai permintaan. Nobi Nobita dan teman-temannya juga memiliki banyak keinginan dan biasanya Doraemon akan berusaha memenuhinya, walaupun kelihatannya mustahil. Misalnya, mereka pernah meminta Doraemon untuk mengubah kaca menjadi logam, sehingga mereka tidak perlu kuatir kaca tersebut akan pecah terkena lemparan bola.

Tahapan kedua adalah internal organisasi karena unit-unit yang telah disampaikan sebelumnya, terutama berkaitan dengan penggambaran anak-anak, saling berkaitan antara komik yang satu dengan komik yang lain. Maksudnya, penggambaran anak-anak dalam komik Doraemon juga dapat ditemukan dalam beberapa komik Jepang lainnya yang juga menjadikan anak-anak sebagai tokoh utamanya, antara lain Komik Hai, Miiko!, karangan Ono Eriko, diterbitkan oleh PT. Gramedia; Komik Ninja Hattori, karangan Fujiko Fujio, diterbitkan oleh PT. Gramedia; dan Komik Kobo-chan, karangan Masashi Ueda, diterbitkan oleh Elex Media Komputindo. Dari beberapa contoh komik Jepang yang terbit di Indonesia, representasi anak-anak yang ditampilkan dalam komik-komik di atas hampir serupa, dengan kata lain, anak-anak digambarkan sebagai sosok yang nakal, sedikit cengeng, suka bertengkar dengan teman-temannya, suka membantah perintah orangtua, namun dilain sisi, mereka juga digambarkan sebagai anak yang manis, suka membantu, sayang terhadap binatang dan mempunyai keingintahuan yang besar terhadap sesuatu.

Tahapan ketiga dikatakan sebagai penafsiran yang disarankan karena melalui komik Doraemon terdapat penafsiran tertentu mengenai representasi anakanak yang terbangun sehingga pada akhirnya akan muncul ideologi baru berkaitan dengan anak-anak. Di Jepang, anak-anak seusia Nobi Nobita dan teman-temannya yang masih sekolah di Sekolah Dasar selalu berjalan kaki jika pergi dan pulang dari sekolah. Di Indonesia, tidak semua anak-anak berjalan kaki saat pergi dan pulang dari sekolah. Memang ada juga yang berjalan kaki saat pergi dan pulang sekolah, dengan berbagai alasan, namun berbeda dengan anak-anak di Jepang yang seluruhnya berjalan kaki saat pergi dan pulang sekolah. Dari contoh sederhana tersebut dapat dikatakan bahwa anak-anak di Jepang lebih mandiri ketimbang anakanak di Indonesia

Berdasarkan keseluruhan sistem gagasan tadi maka ketika suatu gambaran disajikan secara berulang-ulang, dalam hal ini berkaitan dengan representasi anakanak melalui komik Jepang tersebut, maka pada akhirnya akan membentuk suatu pemaknaan atau pemikiran baru/ideologi baru dalam masyarakat tentang anak- 
Fransiska Desiana Setyaningsih : Representasi Anak-Anak Melalui Komik Doraemon Berdasarkan Pendekatan Image System

anak. Sehingga anggapan yang muncul berkaitan dengan anak-anak adalah anakanak yang mempunyai sifat dan bertingkah laku seperti tokoh-tokoh yang tergambar dalam komik seperti Doraemon, Hai Miiko!, Ninja Hattori dan Kobochan

\section{Sistem Mediasi}

Terbentuknya suatu makna baru dalam masyarakat berkaitan dengan representasi anak-anak juga semakin diperkuat pada tahapan mediasi atau perantara yakni melalui: mediasi teknologi dan mediasi sosial. Mediasi teknologi tentu saja merujuk pada intervensi teknologi komunikasi dalam interaksi sosial. Teknologi komunikasi modern pada akhirnya memainkan peran dalam hal penyampaian nilai, perspektif dan gagasan kepada masyarakat dari berbagai usia, budaya dan kelas sosial. Jika dikaitkan dengan representasi anak-anak yang ditampilkan melalui beberapa komik. Di Indonesia sendiri, komik-komik Jepang tersebut juga mudah ditemukan, sehingga tidak mengherankan jika kemudian anak-anak mengidolakan tokoh-tokoh yang digambarkan dalam komik yang mereka baca. Bahkan dapat dikatakan membanjirnya komik-komik Jepang menunjukkan bahwa komik Jepang tersebut lebih menguasai pasaran komik di Indonesia daripada komik buatan Indonesia sendiri.

Selain melalui komik sebagai medianya, banyak juga program-program acara di televisi yang juga menyiarkan acara dengan tokoh anak-anak didalamnya, baik dalam bentuk kartun maupun bukan. Misalnya, cerita Doraemon selain dapat dibaca melalui komik, juga bisa disaksikan melalui televisi. Bukan hanya itu, cerita Doraemon kemudian juga dibuat dalam bentuk layar lebar, dengan kata lain, masyarakat juga dapat menyaksikannya melalui bioskop-bioskop, misalnya film Doraemon di Kerajaan Matahari, Doraemon dan Labirin Kaleng, Doraemon Petualangan di Luar Angkasa dan sebagainya.

Oleh karena itu ketika komik kemudian diterjemahkan ke televisi atau layar lebar maka transformasi tokoh-tokoh dari media cetak ke media elektronik sudah tentu juga membawa sedikit perubahan berkaitan dengan representasi ideologisnya. Maksudnya, ketika sebuah cerita diterjemahkan dari satu teknologi ke teknologi yang lain maka ideologi yang diajarkan sedikit banyak juga akan berubah (walaupun tidak sampai merubah keseluruhan ideologi yang ingin disampaikan). Martin-Barbero (dalam Lull, 1995) menyebutkan bahwa sebuah media bukan sebagai sarana yang menghantarkan gagasan atau ide dari satu tempat ke tempat yang lain, melainkan media tersebut sendiri merupakan suatu bentuk yang subjektif, interpretif dan ideologis.

Mediasi sosial, ketika bahasa maupun kode komunikasi lainnya yang diperoleh dan dipelajari melalui media yang disebarluaskan melalui teknologi kemudian diperkuat dalam konteks interaksi setiap hari maka ideologi yang diperoleh juga menjadi normal dan terkenal dalam pergaulan sosial yang rutin. Pada saat semua ini berlangsung, proses inilah yang kemudian dikenal sebagai proses mediasi sosial. Representasi ideologis dari media dikenali, diinterpretasi, disunting dan digunakan oleh masyarakat dalam konstruksi sosial mengenai kehidupan sehari-hari (Lull, 1995). 
Oleh karena itu tidak mengherankan jika anak-anak kemudian sering memakai ungkapan-ungkapan yang dikenalnya melalui atau mengacu pada tokohtokoh yang dilihatnya dalam komik, film maupun program acara di televisi. Bahkan kata-kata yang kadang dirasakan tidak memiliki arti apa-apa bisa mendapatkan kekuatan ideologis yang besar ketika disebarluaskan dalam masyarakat.

Sebut saja misalnya ketika kemudian ada anak yang suka menangis maka oleh teman-temannya ia dijuluki "Nobita" salah satu tokoh dalam komik Doraemon yang memang dikenal juga sebagai anak cengeng dan manja. Orang atau anak yang mengenakan kacamata seperti kacamata Nobi Nobita, maka orang tersebut kemudian dipanggil "Nobita" oleh teman-temannya. Contoh lain misalnya, banyak anak (tidak jarang remaja atau orang dewasa) memimpikan memiliki "Pintu Kemana Saja" atau "Baling-Baling Bambu", peralatan Doraemon yang sering dikeluarkan yang bisa mengantarkan mereka pergi ke suatu tempat dengan cepat, mudah dan sesuai keingian, sehingga misalnya ketika terjebak kemacetan atau merasa bosan, maka mereka akan berkata "hei...baling-baling bambu...." atau "ayo...cepat keluarkan pintu kemana saja...". Hal lainnya adalah jika seorang anak memiliki badan yang besar dan kuat, oleh teman-temannya dijuluki Gian yang merujuk pada salah satu teman Nobi Nobita yang digambarkan berbadan besar dan kuat.

\section{Representasi Anak-Anak Melalui Komik Doraemon}

Jika Mu'jizah, dalam tulisannya berjudul Representasi Anak dalam Karya Arswendo Atmowiloto Studi Cerita Anak Tahun 1970-an, yang dipublikasikan melalui Jurnal Kandai, menyimpulkan bahwa adalah dunia anak dalam dunia bermain Arswendo menjadi selingan hidup, bukan sesuatu yang dominan. Hal ini dikarenakan anak-anak harus mencari nafkah untuk melanjutkan hidup (2014). Maka representasi anak-anak dalam komik Doraemon yang merupakan komik keluaran Jepang sedikit berbeda.

Anak-anak yang digambarkan dalam komik Doraemon tidak berbeda dengan gambaran anak-anak pada umumnya yang selama ini dipahami oleh masyarakat, yakni: senang bermain. Anak-anak pada umumnya sangat suka bermain. Segala benda bisa dijadikan sebagai mainan, baik benda hidup maupun benda mati sehingga hampir sebagian waktu bisa dihabiskan dengan bermain. Anak-anak biasanya bermain saat di sekolah, sebelum masuk kelas, saat istirahat dan saat sekolah usai dan di rumah. Mereka biasa bermain secara individu (sendirian) maupun secara berkelompok.

Senang bergerak. Selain senang bermain, anak-anak juga sangat senang bergerak seperti berlari, melompat, berputar dan sebagainya. Dengan banyak bergerak, anak-anak secara tidak langsung melatih fisiknya agar semakin kuat dan sehat. Namun kadang-kadang gerakan-gerakan yang dilakukan anak-anak bisa membahayakan dirinya maupun orang lain yang ada disekitarnya.

Anak cengeng. Umumnya anak-anak usia sekolah dasar masih suka menangis. Biasanya mereka menangis jika jatuh atau berkelahi dengan sesama mereka. Ketika anak-anak sering menangis, baik ada penyebab maupun tidak ada penyebab mereka kerap diberi julukan anak cengeng. Demikian juga bila ada anak yang nakal tetapi sering menangis maka anak tersebut juga disebut anak cengeng. 
Senang meniru. Anak-anak usia sekolah dasar umumnya masih suka meniru apa saja yang dilihatnya, baik melalui majalah maupun tayangan televise. Kebanyakan anak-anak meniru tokoh yang dikaguminya. Peniruan tersebut kadang hanya sebatas cara berpakaian atau berbicara tetapi tidak jarang anak-anak meniru keseluruhan dari tokoh tersebut.

\section{Simpulan}

Berdasarkan pembahasan mengenai representasi anak-anak dalam komik Doraemon yang dilihat dari sistem gagasan dan sistem mediasi yang merupakan unsur pembentuk image system, dengan masing-masing komponen di dalamnya diperoleh gambaran bahwa anak-anak yang ditampilkan melalui komik Doraemon adalah anak-anak senang sekali bermain dan bergerak. Anak-anak juga digambarkan sebagai sosok yang cengeng atau mudah menangis, ini wajar karena anak-anak terutama usia sekolah dasar sebagaimana yang ditampilkan dalam komik Doraemon mudah sekali menangis.

Satu lagi representasi anak-anak yang ditampilkan melalui komik Doraemon adalah suka meniru. Anak-anak diandaikan sebagai kain putih yang masih polos, apa yang mereka lihat akan mereka tiru. Sehingga ungkapan anakanak adalah peniru ulung tidaklah berlebihan.

Dengan demikian, anak-anak yang direpresentasikan melalui komik Doraemon tidak begitu saja terjadi. Sebagai salah satu komik Jepang yang digemari oleh masyarakat termasuk di Indonesia, representasi anak-anak dalam komik tadi merupakan hasil konstruksi dari kehidupan sehari-hari anak-anak di Jepang. Sistem gagasan dan sistem mediasi turut membantu terbentuknya representasi masyarakat terhadap anak-anak.

Pandangan atau anggapan yang terbentuk melalui image system tadi, pada akhirnya akan diterima sebagai sesuatu yang sistematis dalam benak masyarakat berkaitan dengan image anak-anak khususnya usia sekolah dasar. Keadaan ini semakin diperkuat jika kemudian, pandangan atau anggapan tersebut disebarluaskan melalui media teknologi dan sosial, misalnya melalui percakapan sehari-hari.

\section{Ucapan TerimaKasih}

Ucapan terima kasih penulis berikan kepada LPPM Universitas Widya Mandira yang telah membiayai penelitian ini dan kepada pihak Fakultas Ilmu Komunikasi Universitas Tarumanagara yang telah mempublikasikan hasil penelitian ini.

\section{Daftar Pustaka}

Kriyantono, Rachmat. (2008). Teknik Praktis Riset Komunikasi. Jakarta: Kencana Prenada Media Group.

Lull, James. (1995). Media, Communication, Culture. A Global Approach. Polity Press. 
Mu'jizah. (2014). Representasi Anak dalam Karya Arswendo Atmowiloto: Studi Cerita Anak Tahun 1970-an. Jurnal Kandai, hal 231-245, diakses 20 Januari 2019 terarsip di: http://ojs.badanbahasa.kemdikbud.go.id/jurnal/index.php/kandai

Wardhani, Khrista Jaya, Bing Bejo Tanudjaja dan Baskoro Suryo Banindro. (2013). Studi Representasi dan Konstruksi Gender dalam Tokoh Komik Bergaya Manga "My Premium Girl". Jurnal DKV Adiwarna, hal 1-18, diakses 20 April 2016 terarsip di: https://www.neliti.com/publications/86839/studirepresentasi-dan-konstruksi-gender-dalam-tokoh-komik-bergaya-mangamy-prem

Widyastuti, Dhyah Ayu Retno \& Mustika Kuri Prasela. (2009). Efektivitas Komik Saku sebagai Media Pemilih dan Pemilu bagi Perempuan Marginal. Jurnal Ilmu Komunikasi, hal 209-226, diakses 29 Juni 2016, terarsip di: https://ojs.uajy.ac.id/index.php/jik/article/view/192/281

Zpalanzani, Alvanov dan Yasraf Amir Piliang. (2010). Framing, Pencitraan dan Panduan Grafis dalam Image Sekuensial pada Komik Perempuan dan Komik Perempuan Indonesia Kontemporer. Jurnal Komunikasi Visual: Wimba, hal 15-24, diakses 27 Juni 2016, terarsip di: https://jurnalwimba.com/index.php/wimba/article/download/37/pdf_10 